Прегледни научни рад

УДК 811.163.41`272

378.61(497.11):811.163.41

Примљен: 31. марта 2021.

Прихваћен: 5. маја 2021.

Драгиша П. Бојовић ${ }^{1}$

https://doi.org/10.46630/phm.13.2021.03

Универзитет у Нишу

Филозофски факултет

Департман за србистику

\title{
ОД ОБНОВЕ СРБИСТИКЕ ДО ИМЕНА ДЕПАРТМАНА ${ }^{2}$
}

У раду су представљени најзначајнији догађаји и процеси у последњој обнови србистике, која се везује за име професора Петра Милосављевића, као и за друге филологе окупљене око Покрета за обнову србистике. Посебна пажња је посвећена оснивању Друштва за обнову србистике у Приштини. У завршном делу рада акценат је стављен на развој националне филологије (посебна на фазе промена имена студијског програма и департмана) на Филозофском факултету у Нишу. Истиче се значај установљења и постојања имена србистика у оквиру студија српског језика и књижевности на овом факултету.

Кључне речи: србистика, обнова србистике, Петар Милосављевић, Филозофски факултет у Нишу, Департман за србистику

Проучавање српског језика и књижевности на универзитетима у Србији, у некадашњој Југославији, као и у свету, има релативно дугу историју, али је праћено и политичким и културолошким променама и изазовима, који су то проучавање често одводили на научну странпутицу. Најчешће се то огледало у губљењу националног имена језика, водило је у његово маргинализовање, али често и у злоупотребу. Стварање две Југославије (монархистичке и комунистичке) праћено је политичким компромисима, али и идеолошком искључивошћу, при чему српска политичка елита није била у стању да створи бенефите након победе српског народа у Првом светском рату, а нова комунистичка елита је жртвовала читаву традицију српског народа, па и достигнућа српске науке, нарочито националне филологије. Стварање поменутих држава доводило је до, у најмању руку, незграпног именовања језика, прво као српско-хрватско-словеначки, а потом као српскохрватски односно као 1 dragisa.bojovic@filfak@ni.ac.rs

2 Рад је настао у оквиру пројекта Србистика на Филозофском факултету у Humy, број 100/1-10-9-01. 
хрватскосрпски. Оба назива имају политичку позадину, која датира из времена пре стварања Краљевине Срба, Хрвата и Словенаца, односно Краљевине Југославије. Још је у време илирског покрета и оснивања Југославенске академије знаности и умјетности у Загребу створена основа за потискивање једино научно утемељеног имена језика којим Срби говоре, а то је српски језик, и то књижевног језика, који је утемељио Вук Караџић, и назвао га српским дефинишући, при томе, да је штокавско наречје српско наречје, а да су сви штокавци Срби без обзира које су вероисповести (православни, римокатолици, муслимани). Када је реч о чакавцима, Вук је сматрао да су они национални Хрвати, а да су Словенци кајкавци (KOVAČEVIĆ 2002: 248). Овакво мишљење у деветнаестом веку заступали су многи лингвисти, међу њима и најугледнији, као што су: Добровски, Копитар, Шафарик, Миклошић и други. Може се рећи да је Вук Стефановић Караџић утемељивач србистике, а да је његов ученик, Ђура Даничић, дао један од важнијих доприноса успостављању сербокроатистике. Управо је оснивање ЈАЗУ 1867. године и постављење Ђуре Даничића за њеног секретара представљало прекретницу у злоупотреби имена српскога језика, који добија свој појмовни пандан у хрватском језику. Тада Даничић у научну употребу уводи израз хрватски језик, тамо где му није место, и постаје уредник Рјечника хрватскога или српскога језика. Снажан замајац оваквим тенденцијама дају и Јагић и Штросмајер, а велики број српских филолога, од тада па до данас, свесно или несвесно спроводе хрватски филолошки програм на српским етничким просторимa.

Упркос неповољним политичким, идеолошким и културолошким приликама, у српском народу и српској науци никада се није угасила идеја о обнови србистике, односно о враћању на изворне научне принципе националне филологије, коју је утемељио Вук Стефановић Караџић. Прва обнова србистике настаје у време великана српске науке - Стојана Новаковића и Љубе Стојановића. Поред других значајних послова, које је обављао, Стојан Новаковић је дао кључни допринос обележавању стоте годишњице рођења Вука Караџића. Новаковић се враћа Вуковим принципима сматрајући да Срби и Хрвати имају један књижевни језик, а то је српски, који Хрвати од времена илирског покрета користе и као свој књижевни језик. Новаковић износи и предлог да Српска краљевска академија почне са припремама за издавање Речника српскога книжевног и народног језика, што је био још један одговор Даничићевим активностима у Загребу. На Новаковићевим позицијама обнове србистике био је и Љуба Стојановић, што се најбоље види из његове академске беседе изговорене 1896. године. Међу онима који су били свесни Даничићевих странпутица обавезно треба поменути и великог Лазу Костића, а знача- 
јан допринос овој првој обнови србистике дали су и поједини књижевни историчари, фолклористи, етнолози, историчари и други. Међутим, победа идеје југословенства, након велике епопеје српског народа у Првом светском рату, изнова је маргинализовала велика прегнућа и научне подухвате обнављача српске националне филологије. Њена агонија траје током целог двадесетог века, све до распада Југославије деведесетих година овог века.

У разматрању теме нашега рада нарочито је важно питање друге обнове србистике, коју везујемо, пре свега, за име Петра Милосављевића, професора Филозофског факултета у Новом Саду. ${ }^{3}$ Поред Милосављевића, изузетно важан допринос овој обнови, на различите начине, дали су професори: Милош Ковачевић, Радмило Маројевић, Слободан Костић, Душко Певуља и други.

Ова обнова нашла је своје плодно тло и на Филозофском факултету у Нишу, како преко прихватања кључних принципа обнове србистике, тако и на симболичком плану преко научног усвајања појма србистика и именовања департмана за националну филологију тим именом. Враћање појму србистика ${ }^{4}$ дешава се у последњим деценијама двадесетог века. Први ово име употребљава Радмило Маројевић у књизи Ћирилииза на раскршћу векова (MAROJEVIĆ 1991: 131). Ипак, кључни догађај је оснивање Друштва за обнову србистике у Приштини, 9. октобра 1997. године. Пре тога, на Видовдан исте године, у Народној и универзитетској библиотеци, обзнањен је настанак Покрета за обнову србистике. Научно утемељење и претходницу у оваквим одлукама треба тражити у објављивању три књиге Петра Милосављевића у Приштини, у издању Народне и универзитетске библиотеке, захваљујући подршци тадашњег управника Слободана Костића, професора Филолошког факултета у Приштини. Реч

3 Петар Милосављевић је рођен 1937. године у Доњој Сварчи (Топлица). Студије је завршио на Филозофском факултету у Новом Саду, где је докторирао на тему Поетика Момчила Настасијевића. На овом факултету предавао је Теорију кюижевности и Методологију проучавања кюижевности. Предавао је на постдипломским студијама у Приштини, Никшићу, Бањој Луци и Српском Сарајеву. Аутор је више књига из области науке о књижевности и србистике. Систематизоване ставове о србистици изложио је у књизи Увод у србистику (MILOSAVLJEVIĆ 2002).

О његовој књижевно-теоријској мисли одбрањена је докторска теза на приштинском Филозофском факултету. Види: ALEKSIĆ 2018. Ту је указано и на Милосављевићев значај у обнови србистике.

4 Колико је познато, први је овај појам употребио Јозеф Добровски, „патријарх” славистике, у латинској варијанти serbica. Он је тако у првој књизи зборника Слованка (Slowanka, 1814) назвао подручје које се бавило српских филолошким темама. Касниje ће Миклошић издати српске ћирилске споменике у књизи под називом Monumenta Serbica (1858). Појам србистика се први пут у неком речнику српског језика појавио, колико нам је познато, 2007. године. Реч је о Речнику српскога језика Матице српске. У њему је србистика дефинисана као „наука о српском језику и српској књижевности”. 
је о књигама: Српски национални програм и српска книжевност (1995), Систем српске кюижевности (1996) и Срби и юихов језик (1997). Пре приштинске промоције књиге су промовисане и у Нишу, а о значају ових промоција аутор каже следеће: „На представљању мојих трију приштинских књига у нишкој Библиотеци 'Стеван Сремац' (уредник Марија Бургић) 4. јуна 1997. говорили смо др Јордана Марковић, доцент на Катедри за српски језик нишког Филозофског факултета и ја. Изгледа да смо успели да дочарамо колико је ситуација у српској националној филологији неповољна. Питали су нас: Видимо какво је стање - реците шта да се ради? Покушао сам да одговорим, али својим одговором нисам био задовољан. Прави одговор дао сам три недеље касније приликом представљања истих књига у Народној и универзитетској библиотеци у Приштини, током Видовданских свечаности, на првом приштинском Салону књига. Рекао сам јасно: Треба обновити србистику" (MILOSAVLJEVIĆ 2000: 8). Треба додати још да је професор Милосављевић годину дана раније, 1996. године, у Новом Саду, у оквиру округлог стола Руски језик. Русистика, Српски језик. Србистика (у организацији Филолошког факултета из Београда) говорио на тему: Србистика - станье и перспективе. Рад је објављен као поговор његовој књизи Срби и ғьихов језик (MILOSAVLJEVIĆ 1997). Важно саопштење имао је и на Четрнаестом конгресу славистичких друштава Југославије, у Будви, октобра 1997. године. На пленарној седници имао је излагање Обнова србистике.

Прекретницу у организованим активностима за обнову србистике представља оснивање Друштва за обнову србистике у Приштини. На оснивачкој скупштини Друштва за председника је изабран проф. др Слободан Костић, за потпредседника мр Драгиша Бојовић, а за секретара мр Голуб Јашовић. Већ следеће године је почео да излази часопис Cрбистика/Serbica. Уредници су били Петар Милосављевић и Слободан Костић, а секретар уредништва Драгиша Бојовић. Приликом оснивања Друштва новоизабрани председник је истакао: „Група филолога из Приштине, којима су идеје Покрета за обнову србистику блиске, јер су утемељене на аутентичној српској филолошкој традицији, одлучила је да помогне да се те идеје почну спроводити у живот. Тако је дошло до формирања овога Друштва. Сматрамо да је природно што је први центар Покрета за обнову србистике настао баш овде, у средини у којој су идеје покрета најпре наишле на подршку. Обнова србистике је, међутим, општесрпски задатак. Верујемо да ће се слични центри ускоро основати и у другим културним срединама у српским земљама и међу Србима у расејању и да ће многе институције и филолози деловати у овом духу" (BOJOVIĆ 1998: 119).

Идејни творац оснивања Покрета за обнову србистике, профе- 
сор Петар Милосављевић, говорио је о значају обнове србистике и о документима, који су пратили оснивање Покрета: Платформа Покрета за обнову србистике и Мемоар о очувану и унапређену српског језика, српске књижевности и српске саборности. У Платформи је истакнуто да „Покрет за обнову србистике као један од својих главних циљева има: да спречи стварање неке србистике која би почивала на остацима распаднуте сербокроатистике, према жељама и пројекцијама туђег филолошког центра. Циљ Покрета је: обнова србистике као дисциплине која је већ постојала, која је плодно деловала и чији је први човек Вук Караџић био један од првака европске филологије 19. века." Поред тога, професор Милосављевић је често истицао да покрет, поред обнове филолошке традиције, има и посебан задатак у духовној обнови, односно духовном преображењу (MILOSAVLJEVIĆ 1998: 14). ${ }^{6}$

Иако је рат 1999. године озбиљно пореметио планове и активности Покрета и Друштва за обнову србистике (Срба и њихових институција није више било у Приштини), обнова активности у обнови србистике лоцирана је у Косовској Митровици, на Филозофском факултету (који је у међувремену обновио рад обједињавањем некадашњег Филозофског и Филолошког факултета). ${ }^{7}$ Факултет је 2002. године био организатор научног скупа „Дело Петра Милосављевића и србистика” и издавач истоименог зборника. ${ }^{8}$ На скупу је још једном истакнута незаменљива улога професора Милосављевића и његов „национални подвиг, који се огледа у обнови унижене српске филологије" (KOSTIĆ 2002: 194). Приштински Филозофски факултет, сада са седиштем у Косовској Митровици, биће и издавач веома значајне Милосављевићеве књиге Увод у србистику

5 Платформа и Мемоар су више пута објављивани. Посебно место имају у првом броју часописа Србистика, 53-68.

6 Значај овог задатка се и данас препознаје и истиче. Тако професор Богољуб Шијаковић истиче да је србистика мултидисциплинарни задатак наше науке и културе, те да је православна духовност средишњи момент заснивања и обнове србистике (ŠIJAKOVIĆ 2021: 499-500). Може се рећи да нема језика без духовности, јер ,језик је мерило нашег трајања, ризница оног богатства које нема цену, стуб који спаја нашу прошлост и нашу будућност, језик је оно што мач није могао да исече, што метак није могао да пробије, што туђин није могао да присвоји; наш језик је војска коју нико није победио, јер има војсковођу који се зове Реч српска. Тај језик има сладост оне соли о којој је говорио Свети Сава својим ученицима, новопостављеним епископима, поручивши им: Ако ко од вас уздође ка књигама, нека буде сладак сољу нашега језика. Тај језик, у којем је Христос (јер он је со), највећа је брана бљутавости и смрти. Зато је наш језик жив, сладак, бесмртан. Његова старина се мери будућим трајањем, а не прошлим вековима. Ти векови су нам само темељ неразрушивог дома, у којем је језик домаћин памћења" (BOJOVIĆ 2016: $56)$.

7 О неким изазовима обнове србистике видети: MILOSAVLJEVIĆ 2004: 269-279.

8 Поред саопштења са скупа зборник садржи и делове Биографија и библиографија и Кғьиге и активности (KOSTIĆ, pr. 2002). 
(MILOSAVLJEVIĆ 2002).

У новонасталим околностима један део активности (научни скупови, промоције) спроводи се у Новом Саду. Поводом десетогодишњице Покрета за обнову србистике у овом граду се 2007. године организује Међународни научни скуп Српско питағе и србистика. ${ }^{9}$ Идеје о обнови србистике, упркос идеолошким и квазинаучним отпорима, налазиле су плодно тло у многим срединама. Континуирано и постепено оживљавање србистике долази до изражаја и у Нишу, на Филозофском факултету, али и другим институцијама и удружењима. Сарадници Покрета и часописа Србистика били су и Горан Максимовић, Јован Пејчић и Драгиша Бојовић (наставник и у Нишу од 2002. године).

Студије српског језика и књижевности на овом факултету постоје од 1987. године и њихово име и наставни програм пратили су судбину србистике на југословенским просторима. Студијска група за српскохрватски језик и југословенску књижевност је основана 1987. године. Након неколико година (школске 2000/2001) године долази до трансформације постојећег студијског програма у два: Српски језик и књижевност и Кюижевност и српски језик, чиме студијама језика враћа њихово српско име. Реформа високог школства наметнула је систем акредитације, тако да је 2006. године формиран јединствен студијски програм под именом Србистика. Колико нам је познато, први пут неки студијски програм на неком факултету где се изучава национална филологија добија име србистика. Одлуком Савета Универзитета у Нишу раније катедре су преименоване у департмане: Департман за српски језик и Департман за српску и компаративну књижевност. ${ }^{10} \mathrm{У}$ новој реорганизацији департмана, 2020. године, два некадашња департмана фузионишу се у један: Департман за србистику, чиме, поред већ тако именованог студијског програма, и департман добија име србистике. ${ }^{11}$

Поред значаја враћања имену србистика, који није само симболички, студије националне филологије на Филозофском факултету у Нишу васпостављене су на темељним принципима србистике као науке, на њеној вуковској парадигми. ${ }^{12}$ То потврђује сам студијски програм, наставни садржаји предмета, афирмација србистике у ужем и ширем смислу преко изборних предмета, враћање прогнаних писаца у те садржаје (Драгиша Васић, Григорије Божовић и други), изучавање великих српских мислилаца XX века (Николај Велимировић, Јустин Поповић) као 9 Објављен је и истоимени зборник.

10 Видети: MAKSIMOVIĆ, OSMANOVIĆ 2017: 447-461; DIMITRIJEVIĆ 2012: 113-130. 11 У новом предлогу акредитације програм на свим нивоима студија на Департману за србистику носи назив Србистика.

12 О Вуков(ск)ој парадигми, насупрот Јагићев(ск)ој сербокроатистичкој видети: KOVAČEVIĆ 2002: 125-132. 
један од знакова духовне обнове, научне конференције, издавачка делатност. ${ }^{13}$ И овај рад настаје као део пројекта Србистика на Филозобоком факултету у Нишу, чији је носилац управо Департман за србистику.

Када је реч о другим факултетима, србистичко име присутно је на Филозофском факултету у Источном Сарајеву и Филолошком факултету у Бањој Луци. На овим факултетима српски језик и књижевност се изучавају на катедрама које се званично зову Катедра за србистику. На бањалучком факултету од 2016. године се организује научна конференција Србистика данас, а од 2020. Philologia Serbica. У најзначајније изучаваоце и промотере србистике спада и професор овог факултета Душко Певуља. ${ }^{14}$ На Филолошком факултету у Београду на основним академским студијама Српског језика и кюижевности постоје предмети Увод у србистику I и Увод у србистику II. На докторским студијама Српског језика и књижевности Филолошко-уметничког факултета Универзитета у Крагујевцу изучавају се предмети: Србистика у светлу лингвистичких и книжевних теорија 20. века, Србистика и структурализам и Србистика и савремене теорије. Верујемо да србистичка парадигма заузима важно место и у студијама српске филологије на факултетима, које овде нисмо поменули.

И изван академских институција све више се говори о србистици, као што су средства информисања, организују се семинари (у Вуковом Тршићу „Млади и србистика”), дају се имена издавачким библиотекама (библиотека Андрићевог института „Знамен србистике”), кратко време у Чикагу је деловао Институт за србистику итд. Нема сумње да је много једноставније било изгубити симболе националне филологије, него их повратити и одомаћити, како у науци, тако и у јавном мњењу. „Дух кривотворења” је присутан и данас. ${ }^{15}$ Обнова србистике није једноставан задатак, јер подразумева и неку врсту унутрашње, антрополошке и идентитетске обнове. Зато је улога оних који учествују у томе часна, али нимало једноставна. Но, и ово време рађа посебне духове, који се уздижу и који будућим генерацијама остављају велики залог.

\section{Цитирана литература}

ALEKSIĆ 2018: Aleksić, Slađana. Teorijsko i metodološko delo Petra Milosavljevića, Filozofski fakultet, Kosovska Mitrovica 2018. [orig.] Алексић, Слађана. Теоријско и методолошко дело Петра Милосављевића, Филозофски

13 О издавачкој делатности као сегменту историје србистике на Филозофском факултету у Нишу видети: MARKOVIĆ, JOVIĆ 2014: 197-203.

14 На ову тему проф. Певуља је објавио неколико значајних књига и научних радова. Видети: PEVULJA 2013; PEVULJA 2015; PEVULJA 2019.

15 О једној форми кривотворења видети: BOJOVIĆ 2017: 147-163. 
факултет, Косовска Митровица 2018.

BOJOVIĆ 1998: Bojović, Dragiša, „Društvo za obnovu srbistike - Centar Priština”, Srbistika/Serbica 1, 1998, 117-120. [orig.] Бојовић, Драгиша, „Друштво за обнову србистике - Центар Приштина”, Србистика/Serbica 1, 1998, 117-120.

BOJOVIĆ 2016:Bojović, Dragiša. Muk i zvona. Intervjui, komentari, besede i poslanice, izdanje autora, Niš 2016. [orig.] Бојовић, Драгиша. Мук и звона. Интервјуи, коментари, беседе и посланице, издање аутора, Ниш 2016.

BOJOVIĆ 2017: Bojović, Dragiša, „Apologijom književnosti protiv duha krivotvorenja”, Liceum 18, 2017, 147-163. [orig.] Бојовић, Драгиша, „Апологијом књижевности против духа кривотворења”, Лицеум 18, 2017, 147-163.

DIMITRIJEVIĆ 2012: Dimitrijević, Bojana (priredila). Četrdeset godina Filozofskog fakulteta u Nišu, Filozofski fakultet, Niš 2012. [orig] Димитријевић, Бојана (приредила). Четрдесет година Филозофског факултета у Нишу, Филозофски факултет, Ниш 2012.

KOVAČEVIĆ 2002: Kovačević, Miloš, „Petar Milosavljević o Vukov(sk)oj i Jagićev(sk)oj filološkoj paradigmi”, Delo Petra Milosavljevića i srbistika, priredio Slobodan Kostić, Filozofski fakultet, Kosovska Mitrovica 2002, 245-254. [orig.] Ковачевић, Милош, „Петар Милосављевић о Вуков(ск)ој и Јагићев(ск)ој филолошкој парадигми”, Дело Петра Милосављевића и србистика, приредио Слободан Костић, Филозофски факултет, Косовска Митровица 2002, 245-254.

KOSTIĆ 2002: Kostić, Slobodan, „Stvaralačka ličnost”, Delo Petra Milosavljevića i srbistika, priredio Slobodan Kostić, Filozofski fakultet, Kosovska Mitrovica 2002, 189-195. [orig.] Костић, Слободан, „Стваралачка личност”, Дело Петра Милосавлевића и србистика, приредио Слободан Костић, Филозофски факултет, Косовска Митровица 2002, 189-195.

MAKSIMOVIĆ, OSMANOVIĆ 2017: Maksimović, Jelena, Osmanović, Jelena, „Tri decenije studija srpskog jezika i književnosti na Univerzitetu u Nišu: hronologija, stanje i perspektive”, Philologia Mediana 9, 2017, 447-461.

MARKOVIĆ, JOVIĆ 2014: Marković, Jordana, Jović, Nadežda, „Istorija srbistike na Filozofskom fakultetu u Nišu kroz istoriju njenih publikacija”, Balkanske sinteze, Časopis za društvena pitanja, kulturu $i$ regionalni razvoj 1, 2014, 197-203. [orig.] Марковић, Јордана, Јовић, Надежда, „Историја србистике на Филозофском факултету у Нишу кроз историју њених публикација", Балканске синтезе, Часопис за друштвена питана, културу и регионални развој 1, 2014, 197-203.

MAROJEVIĆ 1991: Marojević, Radmilo. Ćirilica na raskršću vekova. Ogledi o srpskoj etničkoj i kulturnoj samosvesti, Dečje novine, Gornji Milanovac, Srpski fond slovenske pismenosti i slovenskih kultura, Beograd 1991. [orig.] Маројевић, Радмило. Ћирилица на раскрићу векова. Огледи о српској етничкој и културној самосвести, Дечје новине, Горњи Милановац, Српски фонд словенске писмености и словенских култура, Београд 1991.

MILOSAVLJEVIĆ 2004: Milosavljević, Vera. Čuvari imena. Ogledi i rasprave, Miroslav, Beograd 2004. [orig.] Милосављевић, Вера. Чувари имена. Огледи и 
расправе, Мирослав, Београд 2004.

MILOSAVLJEVIĆ 1997: Milosavljević, Petar. Srbi i njihov jezik. Hrestomatija, Narodna i univerzitetska biblioteka, Priština 1997. [orig.] Милосављевић, Петар. Срби и ғихов језик. Хрестоматија, Народна и универзитетска библиотека, Приштина 1997.

MILOSAVLJEVIĆ 1998: Milosavljević, Petar, „Uz prvi broj Srbistike“, Srbistika/Serbica 1, 1998, 5-18. [orig.] Милосављевић, Петар, „Уз први број Србистике“, Србистика/Serbica 1, 1998, 5-18.

MILOSAVLJEVIĆ 2000: Milosavljević, Petar. Srpski filološki program, Trebnik, Beograd 2000. [orig.] Милосављевић, Петар. Српски филолошки програм, Требник, Београд 2000.

MILOSAVLJEVIĆ 2002: Milosavljević, Petar. Uvod u srbistiku, Filozofski fakultet, Kosovska Mitrovica, Trebnik, Beograd 2002. [orig.] Милосављевић, Петар. Увод у србистику. Филозофски факултет, Косовска Митровица, Требник, Београд 2002.

PEVULJA 2013: Pevulja, Duško. Obnova srbistike, Narodna i univerzitetska biblioteka, Banja Luka 2013. [orig.] Певуља, Душко. Обнова србистике, Народна и универзитетска библиотека, Бања Лука 2013.

PEVULJA 2015: Pevulja, Duško. Povratak srbistici, Art print, Banja Luka 2015. [orig.] Певуља, Душко. Повратак србистиии, Арт принт, Бања Лука 2015.

PEVULJA 2019: Pevulja, Duško, „Radmilo Marojević o obnovi srbistike”, Srpski jezik XXIV, 2019, 767-777. [orig.] Певуља, Душко, „Радмило Маројевић о обнови србистике", Српски језик XXIV, 2019, 767-777.

ŠIJAKOVIĆ 2021: Šijaković, Bogoljub, „Bogoslovski doprinos profesora Dragiše Bojovića”, Crkvene studije 18, 2021, 499- 500. [orig.] Шијаковић, Богољуб, „Богословски допринос професора Драгише Бојовића”, Црквене cmудије 18, 2021, 499-500.

Dragiša Bojović

\section{FROM THE RENEWAL OF SERBIAN STUDIES TO THE NAME OF THE DEPARTMENT}

The paper presents the most significant events and processes in the last renewal of Serbian studies, which is related to Professor Petar Milosavljević, as well as other philologists gathered around the Movement for the Renewal of Serbian Studies. Special attention is dedicated to the establishment of the Society for the Renewal of Serbian Studies in Priština. In the second part of the paper, the emphasis is placed on the development of the national philology (especially on the phases of changing the name of the study program and the department) at the Faculty of Philosophy in Niš. The importance of the establishment and existence of the name of Serbian Studies within the study of Serbian language and literature at this faculty is emphasized.

Keywords: Serbian studies, renewal of Serbian studies, Petar Milosavljević, Faculty of Philosophy in Niš, Department of Serbian 